ても腎不全で入院死亡したあのが5例あった。これらは 術直後は十分な利尿があった例で術後の輸液管理の面で 問題があったと反省している. 手術手技の面では外膜側 にフェルト，中膜側，内膜側にうすいダクロン布を補 強し遮断解除前にフィブリン糊を縫合部に十分塗布し $た^{2)}$. AAE 例では冠動脈孔の縫合がより確実に行える

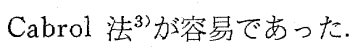

III型解離例では非解剖学的バイパスを多く用いた．前 述したごとく術後早期に上行大動脈の破裂をきたした例 や術後の行血圧，左室肥大など本法に由来する問題点も 少なくないが救命を主眼とする緊急手術であればやむを えないであ万う。和れわれの方法は胸骨正中切開を少し 延長するだけで末梢吻合部に到達できるので比較的短時 間でバイパスが完成でき有用な方法と考えている。一 方, 真性動脈瘤の切迫破裂例にまで本法を応用するのは 異論のあるところであり結局は患者の全身状態と手術侵
襲の大きさに左右されるであ万う。われわれは㓑にあ 3 例全例を救命しており救命の目的は達成された．最後 に高秢者の巨大な真性動脈瘤の問題であるがてれは外科 医が常に決断を迫られ最も悩む問題であろう．しかし必 ず破裂死する運命にあることを考えれば少しであ救命の 可能性を考えるのが外科医の使命である，われわれは前 述のごとく 81 歳の 1 例を救命できた. 今後もさらに手 術手技, 補助手段の改良を含めて胸部大動脈瘤の手術成 績向上のために検討をつづけたい.

以上 33 例の胸部大動脈瘤の緊急手術例について報告 し検討を加えた.

文 献 1) 西内 素名：日心外会誌 13:47, 1983. 2) Cabrol, C. et al.: J. Thorac. Cardiovasc. Surg. 91: 17, 1986. 3) Guilmet, D. et al. : J. Thorac. Cardiovasc. Surg. 77: 316, 1979 .

\title{
128 胸部大動脈瘤手術例の病院死亡例の検討とその対策
}

\author{
国立東京第 2 病院 心臟血管外科, 亀田総合病院*, 防衛医科大学**

\section{高野信篤祝井文治塩入祐世* 田中 勧**}

胸部大動脈瘤手術例中，病院死亡をきたした例の原因 を追求し, 治療成績向上のための方策を検討した.

\section{対象および結果}

昭和 45 年 7 月より昭和 62 年 2 月までの約 17 年間 に当院で施行した広義の胸部大動脈瘤は，42 例であり， 男性 27 例, 女性 15 例で, 年齢は 20 歳より 85 歳, 平均 62 歳であった.

症例㧍よで病院死の詳細は表 1 亿示した. 42 例中病 院死亡例は 11 例, $26 \%$ で, 死亡例の年齢は 36 歳より 74 歳, 平均 $66 \pm 10$ 歳で, 男性 10 例, 女性 1 例であっ た. 病院死亡例之退院例の間には, 年龄, 性別の有意の 差をみとめなかった。

病院死亡例を $\mathrm{A}, \mathrm{B}, \mathrm{C} の 3$ 群佂分け, A 群は死因を 主として技術的要因に帰すべきもの，B群は技術的十患 者側要因が考えられるむの，C群は患者側または現状で はやむをえない要因に帰すべきものとした。

$\mathrm{A}$ 群は 5 例で，うち 4 例が術中の出血がらみのトラブ
表 1 症例および病院死例（）

\begin{tabular}{lcllc}
\hline & 非破裂 & 破 裂 & 切迫破裂 & 計 \\
\hline 真 性 & & & & \\
下行 & $11(2)$ & 1 & & $12(2)$ \\
与部下行 & $4(2)$ & $1(1)$ & $3(2)$ & $8(5)$ \\
上行弓部 & 3 & & & $3(0)$ \\
解離性 & & & & $5(1)$ \\
DeBakey I & $4(1)$ & 1 & & $5(1)$ \\
DeBakey III & $5(1)$ & & & $4(1)$ \\
AAE & $4(1)$ & & & $2(1)$ \\
胸腹部+解離 & & & & $3(0)$ \\
仮 性 & 1 & 2 & & \\
\hline 訫 & $32(7)$ & $5(1)$ & $5(3)$ & $42(11)$ \\
\hline ( ) 病院死 & & & &
\end{tabular}

ルであった〈表 2).

症例 1 は弓部中枢側吻合完了後, 後壁よりの止血任難 橴し； pump 屯使用したが，途中心停止をきたし，台上 死した.

症例 3 はリング付人工血管挿入のため, 大動脈之肺動 脈の剝離をすすめたが, 炎症による癒着が強く, 肺動脈 
表 2 A群（技術的要因）

\begin{tabular}{|c|c|c|c|c|}
\hline & & 瘤部位術前状態 & 死因合併症 & $\begin{array}{l}\text { 死亡ま } \\
\text { 数の日 }\end{array}$ \\
\hline 1. & 74 令 & $\begin{array}{l}\text { 弓部下行 } \\
\text { 粲不全 }\end{array}$ & $\begin{array}{l}\text { 弓部吻合部出血 } \rightarrow \\
\text { 心停止 } \rightarrow \text { Pump }\end{array}$ & 当日 \\
\hline 2. & $63 \hat{o}$ & $\begin{array}{l}\text { 弓部下行 } \\
5 \text { 年前下行瘤手術 }\end{array}$ & $\begin{array}{l}\text { 吻合やり直し } \\
\text { 消化管出血, MOF }\end{array}$ & 15日 \\
\hline 3. & 62 令 & $\begin{array}{l}\text { I 型解離 } \\
+\mathrm{AR}\end{array}$ & $\begin{array}{l}\text { PA よりの出血 } \\
\text { PA 再建, LOS }\end{array}$ & 1日 \\
\hline 4. & 70 우 & $\begin{array}{l}\text { 胸腹部，切迫破裂 } \\
\text { 急性正型解離 }\end{array}$ & $\begin{array}{l}\text { Celiac 吻合部出血 } \\
\text { 大量輸血 } \rightarrow \text { LOS }\end{array}$ & 1日 \\
\hline 5. & & $\begin{array}{l}\text { 下行 } \\
\text { 術後グラフト感染 }\end{array}$ & $\begin{array}{l}\text { 感染グラフト reope } \\
\text { 出血, 意識障害 }\end{array}$ & $\begin{array}{l}64 日 \\
(9 日)\end{array}$ \\
\hline
\end{tabular}

( ) reope 後の日数

後側壁からの出血が強勢となった，結局右肺動脈切断閉 鎖とGore Tex 人工血管による右肺動脈バイパスの作 製を余儀なくされたが，LOS で失った。

症例 4 は胸腹部大動脈瘤に正型解離を併発した例で, 人工血管に SMA 之右腎動脈を内腔吻合した部からの 出血制禦のため，結局他の腹部分枝吻合屯初めからやり 直す破目となった，大量輸血，出血傾向，LOS となっ た.

症例 5 は感染グラフトのため, extra anatomic bypass を施行, 感染グラフト除去中の出血が原因で意識 障害のため死亡した。

症例 2 は下行大動脈瘤手術の既往を有する弓部下行瘤 で，永久バイパスとした末梢側吻合の通過障害のため吻 合のやり直しには時間を浪費した例であった，乙の例で は胸腹部瘤も合併し（放置）侵襲過大となり MOF に いたったあのと考えられた。

B群（表 3 ）は 4 例で，症例 1 は，破裂による術前の shock に加えて，術中低血圧の時間もあり，術後意識障 害，対麻㽻から MOF を招来した。

症例 2 は AAE 亿対する Bentall 手術は予定通り終

表 3 B 群（技術的十患者側要因）

\begin{tabular}{|c|c|c|c|c|}
\hline & & 瘤部位術前状態 & 死因合併症 & $\begin{array}{l}\text { 死亡ま } \\
\text { での日 } \\
\text { 数 }\end{array}$ \\
\hline 1. & 68 令 & $\begin{array}{l}\text { 弓部下行＋下行 } \\
\text { 破裂, 術前 } \\
\text { Shock } 2 \times\end{array}$ & $\begin{array}{l}\text { 意識障害 } \\
\text { paraplegia, MOF }\end{array}$ & 15日 \\
\hline 2. & & AAE, III型解離 & 意識障害 & 42 日 \\
\hline 3. & $68 \hat{\beta}$ & $\begin{array}{l}\text { 下行 (2 力所) } \\
\text { 腎不全 }\end{array}$ & $\begin{array}{l}\text { 消化管出血 } \\
\text { 腎不全, AAA 破裂 }\end{array}$ & 裂 28 日 \\
\hline 4. & 76 상 & $\begin{array}{l}\text { 巨大弓部下行 } \\
\text { 切迫破裂 }\end{array}$ & 喀血 & 7 日 \\
\hline
\end{tabular}

了したが，術後意識障害から回復せず 42 日目に死亡し た．体外循環とも関係があるあのと考えられた，症例 3 は術前腎不全を有する胸部多発瘤で，呼吸不全，消化管 出血, 腎不全, 腹部大動脈瘤後膜出血で死亡した.

症例 4 峙巨大弓部下行瘤で, 瘤空置 + extra anatomic bypass を施行したが，術後喀血にて窒息死した。

$\mathrm{C}$ 群は 2 例で, 1 例は 68 歳男性の而型解離で, 肝炎 から肝旨睡のため術後 5 力月で死亡. 他の例は 72 歳男 性，弓部下行瘤の切迫破裂例で，紅皮症，再生不良性貧 血のため術後 28 日目に失った. 両者と屯輸血の影響と 考えられたが，明確な予防措置はいまだ明確でない，

\section{対策および考察}

全症例中，弓部下行瘤が 8 例中死亡例 5 例之最屯多か った．前記分類でみると， $\mathrm{A}$ 群 $2 ， \mathrm{~B}$ 群 $2 ， \mathrm{C}$ 群 1 例で あった。

手術手技上の対策として，弓部側断端の端端吻合に困 難を感ずる例では，先に発表したでとく ${ }^{1)}$ ，断端の単純 閉鎖と，上行大動脈から下行大動脈への永久バイパスを 行っている. ての方法での最長生存例は 8 年以上経過 し，健在である.

肺動脈後側壁よりの出血は，ポンプ使用の上，肺動脈 を切開して，内腔より損傷部の修復をするの屯一法と考 えている. Pump stand by では，回路の充填を完了し ておくべきであろう。

胸腹部大動脈瘤のごとく吻合部の多い瘤では，いった ん吻合が完成してからは，出血部の確認，補修はきわめ て困難である，追加縫合を必要としない吻合汇留意すべ きであろう。

他部位の瘤病変を有する多発瘤では，血管遮断の影響 も強く，侵襲む過大となりやすく，術前検査とあわせて 適応を慎重に決めるべきと考えた． A 群中 3 例にこのよ うな症例をみとめたが，破裂の risk ああり，手術 risk とのバランスのとり方は必ずし屯容易ではない.

C群の 2 例は輸血が関与した例と考えられるが，自己 血輸血などで, 輸血量の減少飞努力している.

昭和 62 年の第 40 回日本胸部外科学会総会で「胸部 大動脈瘤手術は進歩向上したか」というシンポジゥム22 がもたれた．参加した 7 施設の過去 10 年の症例と手術 (病院) 死亡を集計したとこ万，848 例中 137 例死亡で 死亡率は $16 \%$ であった，病院死亡では， 76 例中 23 例， $30 \%$ という数字もみられた．胸部大動脈瘤手術の成績 にはまだ多くの改善の余地のあることを如実に示してい る. 


\section{総括および結論}

手術成績向上には，術中出血の予防が重要である，綿 密な手術方法, 計画に加え, 手技の習熟は欠加せない が, 手術適応, 麻酔, ポンプなどの入念な準備を励行す るととで，成績改善の余地む大きいと考えられた.

1） 42 例の胸部大動脈瘤手術例のうち 11 例の病院
死亡 (26\%) を認めた，2）このうち技術的な改善で成 績向上が期待できると考えられた症例は 5 例であった. 3) 他の 6 例でも輸血, 麻酔, 補助手段, 手術適応など の面で, 成績向上の可能性が期待できる例と思考した.

文 献 1) 高野信䉆ほか：医療 $36: 778,1982$ 2) シンポ ジウム「胸部大動服濞手術は進歩向上したか」。 日胸外会誌 35 ： 1297, 1987. 